\title{
Physicochemical characterization of ordered mesoporous carbons functionalized by wet oxidation
}

\author{
Michal Marciniak ${ }^{1}$ (D), Joanna Goscianska ${ }^{1}$ (D), and Robert Pietrzak ${ }^{1, \star}$ (D) \\ ${ }^{1}$ Faculty of Chemistry, Adam Mickiewicz University in Poznań, Umultowska 89b, 61-614 Poznan, Poland
}

Received: 20 October 2017

Accepted: 20 December 2017

Published online:

2 January 2018

(C) The Author(s) 2017. This article is an open access publication

\begin{abstract}
Ordered mesoporous carbon obtained by the soft template method was subjected to oxidation with the use of ammonium persulfate or nitric acid. The material was modified in different conditions in order to generate on its surface oxygen functional groups. Functionalization of carbon with nitric acid or ammonium persulfate at low temperatures caused a reduction in its surface area and pore volume. At elevated temperatures, the oxidation with $\left(\mathrm{NH}_{4}\right)_{2} \mathrm{~S}_{2} \mathrm{O}_{8}$ solution brought about an increase in these parameters, which is related, among others, with increased area of micropores. Transmission electron microscopy images confirm that the application of ammonium persulfate as an oxidizer does not lead to structural changes in carbon. FT-IR spectra and Boehm titration results proved that irrespective of the oxidation conditions, the process leads to generation of oxygen functional groups. Their highest content was observed for the carbon sample oxidized by a $5 \mathrm{M}$ solution of $\mathrm{HNO}_{3}$ at $100{ }^{\circ} \mathrm{C}$.
\end{abstract}

\section{Introduction}

Porous materials for a long time have enjoyed much interest because of their unique physicochemical, electric, mechanical and chemical properties following from well-developed surface area and large total pore volume. This group of materials includes activated carbons, activated carbon fibres, carbon molecular sieves, fullerenes, carbon nanotubes, mesoporous silica, metal oxides, zeolites and ordered mesoporous carbon materials [1-5]. The latter materials have uniform pores of the size from the range 2-50 nm, making two- or three-dimensional lattice. They are attractive in quite a range of applications, from adsorbents of large hydrophobic molecules and biomolecules, supports of catalysts-mainly metals and their oxides, components of electrochemical capacitors, electric current sources and lithium-ionic cells to fillers of chromatographic columns [2, 3, 6-9]. There are two main methods proposed for the synthesis of mesoporous carbons: the hard and soft template methods. In 1999 for the first time the ordered mesoporous carbon (OMC) was obtained using mesoporous silica MCM-48 [2]. The strategy of this method was based on formation of carbon polymers inside mesoporous silica as a result of impregnation with sucrose and its carbonization and then removal of the silica matrix. The obtained carbon CMK-1 was the reverse replica of the initial silica MCM-48 [2]. This method prompted intense studies

Address correspondence to E-mail: pietrob@amu.edu.pl 
on the possibilities of obtaining a wide range of carbon replicas and their applications. Many authors have been interested in the synthesis of ordered mesoporous carbons by the hard template method with the use of different silica matrices: MCM-48 [10], SBA-15 [3, 10], SBA-16 [3, 10], KIT-6 [10-12] and carbon precursors (e.g. glucose, xylose, furfuryl alcohol, phenol resins) [2, 3, 6-9]. The materials obtained in this way can successfully replace activated carbons and zeolites (a numerous group of aluminosilicates) in many branches of industry $[2,13,14]$. Their very important property determining the widespread use of these materials is the possibility of controlling their structure and physicochemical properties through the choice of parameters of synthesis and the possibility of their chemical modification.

Another important event in this area was the synthesis of ordered mesoporous carbon by soft template method with the use of surfactants or block copolymers as matrices [10-12]. The soft template method permitted elimination of the use of solid silica matrices, which reduced the stages of synthesis, reduced the cost and made it easier to perform [15-19].

Ordered mesoporous carbons show many interesting properties: large surface area and large pore volume, high uniformity of porous structure, high chemical and thermal resistance and are chemically neutral. However, because of rather poor chemical surface properties restricted by low number of functional groups, they often demand preliminary modification. The most effective and often used method of their modification is oxidation, leading to generation of oxygen functional groups, mainly carboxyl, hydroxyl ones but also lactone carbonyl and ether ones [20]. Usually oxidation is the first step of modification aimed at introduction of other desired functional groups [20-23]. Thanks to appropriate surface modification, these materials can be adsorbents of, e.g. heavy metal ions. The processes of oxidation can be divided, according to the mode of the reaction, into dry, wet and electrochemical. Dry oxidation is performed with oxidizing gases such as oxygen, ozone or carbon dioxide. Wet oxidation is carried out with acid solutions, e.g. nitric, sulphuric or phosphoric, while the most often used is nitric acid, either concentrated or dilute [24-26]. The process of oxidation with nitric acid is effective and can be easily controlled by the acid concentration and temperature of oxidation [27, 28]. Calvillo et al. [29] have oxidized carbon CMK-3 with concentrated and dilute nitric acid solutions and applied the carbon obtained as a support of platinum catalyst in methanol electrooxidation. The catalytic activity of oxidized platinum catalyst was much higher than that of the commercial carbon. Another method for the introduction of oxygen functional groups on the surface of carbons CMK- 3 and CMK- 5 has been proposed by Bazuła et al. [30]. They have oxidized the carbon samples with a solution of nitric acid used in concentrations $0.5,1,2$ and $4 \mathrm{M}$ for a period from $15 \mathrm{~min}$ to $6 \mathrm{~h}$ and in temperatures varied from 50 to $110{ }^{\circ} \mathrm{C}$. The use of low nitric acid concentration and low temperatures was found beneficial for preservation of the ordered structure of CMK-3 and CMK-5. Moreno-Tovar et al. [31] have checked the effect of temperature and time of oxidation reaction of CMK-3 with nitric acid solution on physicochemical properties of this carbon and its adsorption properties towards $\mathrm{Pb}(\mathrm{II})$ and $\mathrm{Cd}(\mathrm{II})$, showing that the most effective adsorbent of these metals was CMK-3 oxidized at $70{ }^{\circ} \mathrm{C}$ for $12 \mathrm{~h}$.

The aim of our study was to check the effect of the type of oxidizing agent on the physicochemical properties of ordered mesoporous carbon obtained by the soft template method. The carbon was subjected to oxidation in different conditions and with the use of ammonium persulfate and nitric acid. The carbon materials obtained were characterized by lowtemperature nitrogen adsorption/desorption, X-ray diffraction, transmission electron microscopy, infrared spectroscopy and thermogravimetric methods. The number of generated oxygen functional groups was determined by the Boehm method [32].

\section{Materials and methods}

\section{Synthesis of ordered mesoporous carbons by soft template method}

The typical synthesis procedure was: $1.875 \mathrm{~g}$ triblock copolymer poly(ethylene oxide)-poly(propylene oxide)-poly(ethylene oxide)-Pluronic F127 (SigmaAldrich) and $1.875 \mathrm{~g}$ resorcinol (Sigma-Aldrich) were dissolved in $15.375 \mathrm{~g}$ of ethanol solution (POCh) in water (weight ratio $\mathrm{C}_{2} \mathrm{H}_{5} \mathrm{OH}: \mathrm{H}_{2} \mathrm{O}$ was $10: 7$ ) at room temperature upon vigorous stirring. After their complete dissolution, $0.12 \mathrm{~cm}^{3}$ of hydrochloric acid 
(POCh, 36\%) and $1.875 \mathrm{~cm}^{3} 37 \%$ of formaldehyde solution (Chempur) were added. The solution was subjected to vigorous mixing until it became turbid. After $2 \mathrm{~h}$, the mixture separated into two layers, the water layer that was removed and the organic layer. The latter was stirred for $72 \mathrm{~h}$ by a magnetic stirrer. The dark-brown monolith obtained was heated for $24 \mathrm{~h}$ in a propylene bottle at $100{ }^{\circ} \mathrm{C}$. After heating, it was subjected to carbonization in a tube furnace in nitrogen atmosphere $\left(5 \mathrm{~h}, 180{ }^{\circ} \mathrm{C} ; 4 \mathrm{~h}, 400{ }^{\circ} \mathrm{C} ; 2 \mathrm{~h}\right.$, $\left.800{ }^{\circ} \mathrm{C}\right)$.

\section{Surface functionalization of mesoporous carbon materials}

The ordered mesoporous carbon obtained by the soft template method, $\mathrm{C}_{\mathrm{ST}}$, contained a small number of surface functional groups, was subjected to oxidation in order to generate oxygen functional groups. The oxidation was carried out with $1 \mathrm{M}$ solution of APS $\left(\left(\mathrm{NH}_{4}\right)_{2} \mathrm{~S}_{2} \mathrm{O}_{8}\right.$-ammonium persulfate) (SigmaAldrich) prepared in a $2 \mathrm{M}$ solution of $\mathrm{H}_{2} \mathrm{SO}_{4}$ (POCh), or with 0.5 or $5 \mathrm{M}$ solutions of nitric acid (Scharlau). To estimate the resistance to oxidation and to get different degrees of modification, the process was performed at different temperatures and for different times:

- Oxidation of $\mathrm{C}_{\mathrm{ST}}$ with $1 \mathrm{M}$ solution of APS: $0.5 \mathrm{~g}$ of $\mathrm{C}_{\mathrm{ST}}$ were placed in a round-bottom flask, flooded with $30 \mathrm{ml}$ of $1 \mathrm{M}$ solution of APS in a $2 \mathrm{M}$ solution of $\mathrm{H}_{2} \mathrm{SO}_{4}$. The reaction was performed at 30,60 or $100{ }^{\circ} \mathrm{C}$ for 6,12 or $24 \mathrm{~h}$ under reflux and upon vigorous stirring.

- Oxidation of $\mathrm{C}_{\mathrm{ST}}$ with nitric acid solution: $0.5 \mathrm{~g}$ of $\mathrm{C}_{\mathrm{ST}}$ were placed in a round-bottom flask, flooded with $30 \mathrm{ml}$ of nitric acid solution of 0.5 or $5 \mathrm{M}$ concentration. The reaction was performed at 70 or $100{ }^{\circ} \mathrm{C}$, for $12 \mathrm{~h}$ under reflux and upon vigorous stirring.

The final step of $\mathrm{C}_{\mathrm{ST}}$ modification was filtration, washing with water and with ethanol. The samples obtained in different conditions and with different oxidizing agents were labelled as follows:

- Oxidation with APS solution: $\mathrm{C}_{\mathrm{ST}^{-}}$APS-30-6h, $\mathrm{C}_{\mathrm{ST}^{-}}$ APS-30-12h, $\mathrm{C}_{\mathrm{ST}}$-APS-30-24h, $\mathrm{C}_{\mathrm{ST}^{-}}$-APS-60-6h, $\mathrm{C}_{\mathrm{ST}^{-}}$ APS-60-12h, C $_{\text {ST }^{-}}$APS-60-24h, C $_{\text {ST }}$-APS-100-6h, $\mathrm{C}_{\mathrm{ST}}$-APS-100-12h, $\mathrm{C}_{\mathrm{ST}}$-APS-100-24h, where 30, 60 and 100 denote the temperatures of the process.
- Oxidation with nitric acid: $\mathrm{C}_{\mathrm{ST}^{-}}-\mathrm{HNO}_{3}-70-0.5, \mathrm{C}_{\mathrm{ST}^{-}}$ $\mathrm{HNO}_{3}-100-0.5, \mathrm{C}_{\mathrm{ST}^{-}}-\mathrm{HNO}_{3}-70-5, \mathrm{C}_{\mathrm{ST}^{-}}-\mathrm{HNO}_{3}-100-5$, where 70 and 100 denote the temperature of the process, while 0.5 and 5 are the concentrations of nitric acid.

\section{Characterization of materials}

\section{Porous structure}

The measurements needed to establish the surface area, pore volume and diameter were made on Autosorb iQ instrument (Quantachrome). Prior to measurements, samples of about $0.2 \mathrm{~g}$ were heated at $400{ }^{\circ} \mathrm{C}$ for $4 \mathrm{~h}$ and then degassed in vacuum at $350{ }^{\circ} \mathrm{C}$ for $3.5 \mathrm{~h}$. Isotherms of nitrogen adsorption/desorption were measured at $-196{ }^{\circ} \mathrm{C}$. Surface area and pore size distribution were calculated by BET (Brunauer-Emmett-Teller) and BJH (Barret, Joyner, Halenda) methods, respectively. Total pore volume and average pore diameter were determined as well. The micropores area was determined by the $t$-plot method.

\section{Powder X-ray diffraction (XRD)}

Small-angle X-ray diffraction (XRD) patterns were obtained on a Bruker AXS DB Advance diffractometer ( $\mathrm{CuK} \alpha$ radiation, $\lambda=0.154 \mathrm{~nm}$ ) with the step size of $0.02^{\circ}$.

\section{Transmission electron microscopy (TEM)}

For TEM measurements, powdered samples were deposited on a grid with a perforated carbon film and transferred to a JEOL 2000 electron microscope operating at $80 \mathrm{kV}$.

\section{Surface oxygen functional groups}

The contents of oxygen functional groups on the surface of $\mathrm{C}_{\mathrm{ST}}$ samples were determined by the Boehm method [32], which permits determination of acid-base properties of the materials studied. The total content of oxygen acidic groups was evaluated by their neutralization with a $0.1 \mathrm{M}$ solution of sodium hydroxide. The excess of base was measured by titration with $0.1 \mathrm{M}$ solution of $\mathrm{HCl}$ in the presence of methyl orange as an indicator. To determine the content of basic oxygen functional groups on the 
$\mathrm{C}_{\mathrm{ST}}$ surface, they were neutralized by a $\mathrm{HCl}$ solution. The excess of $\mathrm{HCl}$ was established by titration with a $0.1 \mathrm{M}$ solution of sodium hydroxide in the presence of methyl orange.

\section{Infrared spectroscopy (FT-IR)}

The structural changes in the oxidized mesoporous carbon samples were studied by FT-IR spectroscopy. The samples were mixed with dry potassium bromide at the rate of $1 \mathrm{mg}$ of the carbon sample per $200 \mathrm{mg} \mathrm{KBr}$. The FT-IR spectra in the range $400-4000 \mathrm{~cm}^{-1}$ were recorded on Varian 640-IR.

\section{Thermal analysis}

Thermogravimetric analysis was performed on an SETSYS 12 instrument made by Setaram. The samples were heated at the rate $5{ }^{\circ} \mathrm{C} / \mathrm{min}$, in nitrogen atmosphere. The analysis lasted for $100 \mathrm{~min}$, and the temperature was varied from 20 to $1000{ }^{\circ} \mathrm{C}$.

\section{Results and discussion}

The isotherms of nitrogen adsorption on mesoporous carbons oxidized with ammonium persulfate or nitric $(V)$ acid solution are present in Figs. 1 and 2. For all activated carbon samples tested, except sample $\mathrm{C}_{\mathrm{ST}}-\mathrm{HNO}_{3}-100-5$, the isotherms were of type IV according to the IUPAC classification, which indicates their mesoporous character. The isotherms show well-marked hysteresis loops. In the isotherms of the initial material $\mathrm{C}_{\mathrm{ST}}$, the loop covered the

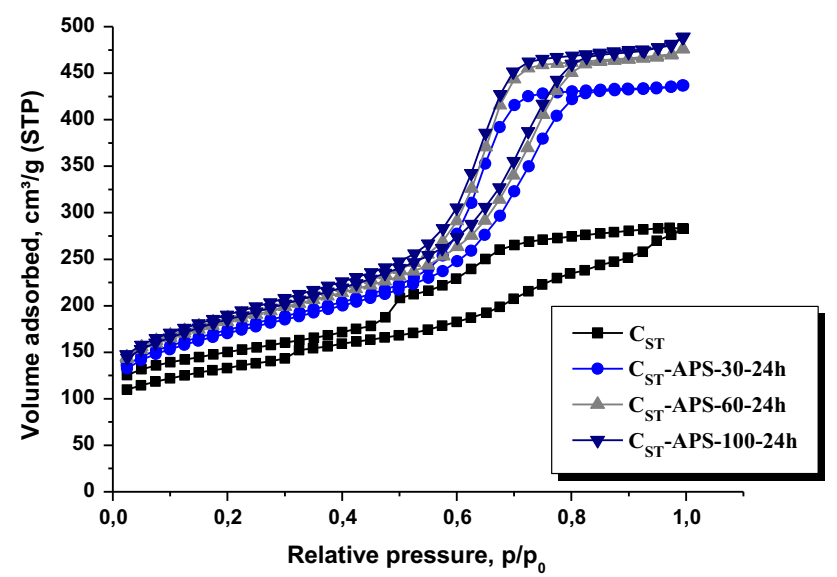

Figure $1 \mathrm{~N}_{2}$ sorption isotherms of pristine $\mathrm{OMC}$ and samples oxidized in acidic APS solution at 30,60 and $100{ }^{\circ} \mathrm{C}$ for $12 \mathrm{~h}$.

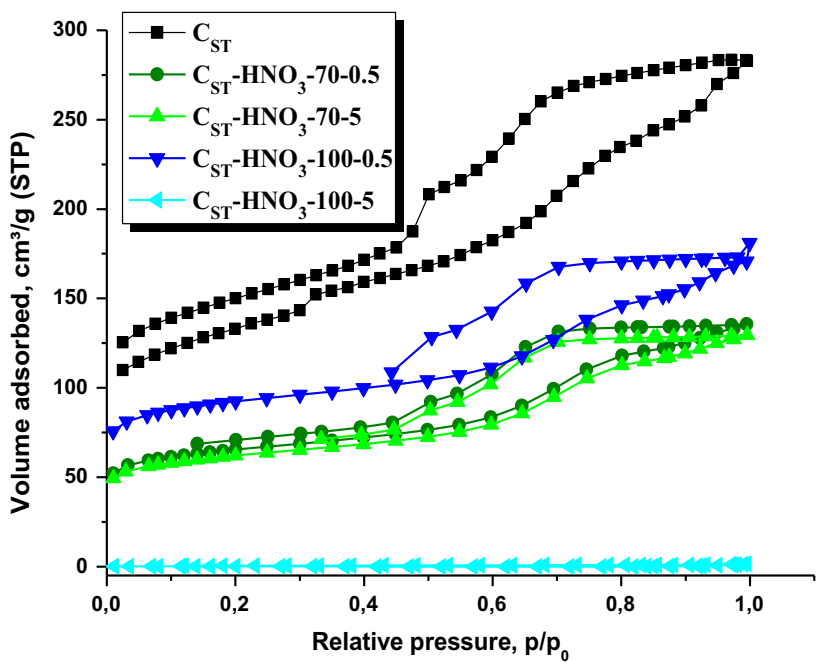

Figure $2 \mathrm{~N}_{2}$ sorption isotherms of pristine OMC and samples oxidized in 0.5 and $5 \mathrm{M} \mathrm{HNO}_{3}$ solutions at 70 and $100{ }^{\circ} \mathrm{C}$.

pressure range $p / p_{0}=0.45-1.0$. For the samples oxidized with ammonium persulfate solution, the hysteresis loops covered the smaller range $p /$ $p_{0}=0.55-0.80$, which suggests a narrow pore size distribution. For the samples oxidized with nitric $(\mathrm{V})$ acid, the situation was different. For samples $\mathrm{C}_{\mathrm{ST}^{-}}-\mathrm{HNO}_{3}-70-0.5, \mathrm{C}_{\mathrm{ST}}-\mathrm{HNO}_{3}-70-5$ and $\mathrm{C}_{\mathrm{ST}^{-}}-\mathrm{HNO}_{3}-$ $100-0.5$, the hysteresis loops occurred in exactly the same pressure range as for the initial material. These materials have much broader pore size distribution than the samples oxidized with ammonium persulfate. For $\mathrm{C}_{\mathrm{ST}}-\mathrm{HNO}_{3}-100-5$, the isotherm of nitrogen adsorption was of type II according to IUPAC classification, which is characteristic of nonporous and macroporous materials.

Table 1 presents the results obtained on the basis of low-temperature nitrogen adsorption/desorption: surface area, micropores area, pore volume and diameter for all samples studied. The surface area of pure mesoporous carbon is $426 \mathrm{~m}^{2} / \mathrm{g}$, while its pore volume is $0.44 \mathrm{~cm}^{3} / \mathrm{g}$. Besides mesopores, it also contains micropores. The type of oxidizing agent, its concentration and duration of the process of modification had significant effects on the textural parameters of the samples. The $\mathrm{C}_{\mathrm{ST}}$ oxidation with a solution of ammonium persulfate at 30 or $60{ }^{\circ} \mathrm{C}$ for $6 \mathrm{~h}$ led to a significant decrease in the surface area and pore volume, relative to the values for the pristine material. The same tendency was observed for the samples oxidized with a $\mathrm{HNO}_{3}$ solution, irrespective of the process conditions. The greatest 
Table 1 Textural parameters of mesoporous carbons

\begin{tabular}{|c|c|c|c|c|}
\hline Sample & $\begin{array}{l}\text { Total surface } \\
\text { area }\left(\mathrm{m}^{2} / \mathrm{g}\right)\end{array}$ & $\begin{array}{l}\text { Total pore } \\
\text { volume }\left(\mathrm{cm}^{3} / \mathrm{g}\right)\end{array}$ & $\begin{array}{l}\text { Average pore } \\
\text { diameter }(\mathrm{nm})\end{array}$ & $\begin{array}{l}\text { Micropore surface } \\
\text { area }\left(\mathrm{m}^{2} / \mathrm{g}\right)\end{array}$ \\
\hline $\mathrm{C}_{\mathrm{ST}}$ & 426 & 0.44 & 4.12 & 151 \\
\hline $\mathrm{C}_{\mathrm{ST}}$-APS-30-6h & 248 & 0.29 & 5.59 & 78 \\
\hline $\mathrm{C}_{\mathrm{ST}}-\mathrm{APS}-30-12 \mathrm{~h}$ & 400 & 0.56 & 4.86 & 177 \\
\hline $\mathrm{C}_{\mathrm{ST}}-\mathrm{APS}-30-24 \mathrm{~h}$ & 556 & 0.68 & 4.67 & 222 \\
\hline $\mathrm{C}_{\mathrm{ST}}-\mathrm{APS}-60-6 \mathrm{~h}$ & 204 & 0.30 & 5.82 & 127 \\
\hline $\mathrm{C}_{\mathrm{ST}}-\mathrm{APS}-60-12 \mathrm{~h}$ & 457 & 0.62 & 5.42 & 220 \\
\hline $\mathrm{C}_{\mathrm{ST}}-\mathrm{APS}-60-24 \mathrm{~h}$ & 595 & 0.74 & 4.94 & 269 \\
\hline $\mathrm{C}_{\mathrm{ST}}-\mathrm{APS}-100-6 \mathrm{~h}$ & 528 & 0.68 & 5.17 & 303 \\
\hline $\mathrm{C}_{\mathrm{ST}}-\mathrm{APS}-100-12 \mathrm{~h}$ & 566 & 0.69 & 4.88 & 345 \\
\hline $\mathrm{C}_{\mathrm{ST}}-\mathrm{APS}-100-24 \mathrm{~h}$ & 607 & 0.76 & 4.99 & 367 \\
\hline $\mathrm{C}_{\mathrm{ST}^{-}}-\mathrm{HNO}_{3}-70-0.5$ & 329 & 0.21 & 3.59 & 147 \\
\hline $\mathrm{C}_{\mathrm{ST}}-\mathrm{HNO}_{3}-70-5$ & 221 & 0.20 & 3.60 & 133 \\
\hline $\mathrm{C}_{\mathrm{ST}}-\mathrm{HNO}_{3}-100-0.5$ & 237 & 0.28 & 3.50 & 221 \\
\hline $\mathrm{C}_{\mathrm{ST}}-\mathrm{HNO}_{3}-100-5$ & 0.7 & 0.002 & 14.60 & 2 \\
\hline
\end{tabular}

reduction in the textural parameters was noted for the $\mathrm{C}_{\mathrm{ST}}$ sample oxidized with a $5 \mathrm{M}$ solution of nitric acid at $100{ }^{\circ} \mathrm{C}$. The reduction in these parameters is related to the fact that modification causes blocking of a part of micropores. Most probably the oxygen functional groups are localized at the entrances to micropores, leading to a decrease in their area and volume. A different situation was observed on oxidation with a solution of $\left(\mathrm{NH}_{4}\right)_{2} \mathrm{~S}_{2} \mathrm{O}_{8}$ at a temperature increased to $100{ }^{\circ} \mathrm{C}$. This material showed a greater surface area and pore volume than pure $\mathrm{C}_{\mathrm{ST}}$, which was related to increased area of micropores. The greatest surface area of $607 \mathrm{~m}^{2} / \mathrm{g}$ and pore volume of $0.76 \mathrm{~cm}^{3} / \mathrm{g}$ were found for the sample oxidized with a solution of APS for the longest time and at the highest temperature, $\mathrm{C}_{\mathrm{ST}}$-APS-100-24h.

XRD diffractograms in the small-angle range of pristine material $\mathrm{C}_{\mathrm{ST}}$ and the products after the treatment in acidic APS solution at 30,60 and $100{ }^{\circ} \mathrm{C}$ for 6, 12 and $24 \mathrm{~h}$ are shown in Fig. 3a-c. Pristine mesoporous carbon obtained by the soft template method shows the ordered but poorly developed hexagonal structure, which is indicated by low-intensity peak at $2 \theta$ values of $0.84-1.0$. Similar results were obtained for the samples oxidized with APS solution at 30 and $60{ }^{\circ} \mathrm{C}$ for $6 \mathrm{~h}$. An increase in the process temperature to $100{ }^{\circ} \mathrm{C}$, irrespective of the process duration, leads to development of the carbon porous structure, manifested as an increase in the intensity of the peak near $2 \theta$ of $0.84-1.0$. The diffractograms of carbon samples oxidized with nitric acid solutions are present in Fig. 4. The pristine carbon and the samples after oxidation with a solution of $\mathrm{HNO}_{3}$ have poorly developed porous structure. The use of nitric acid, which is strongly oxidizing agent, can lead to partial destruction of the porous structure.

TEM images permitted identification of the structures of the samples studied and evaluation of the degree of their ordering. The TEM image of pristine $\mathrm{C}_{\mathrm{ST}}$ (Fig. 5a) shows long channels forming a hexagonal structure of high ordering. The oxidation of $\mathrm{C}_{\mathrm{ST}}$ with a mild oxidizing agent, APS solution, irrespectively of temperature and duration of the process (Fig. 5b, c) had no negative effect on the ordered structure of the carbon material. The same observation was made for the sample oxidized with $0.5 \mathrm{M}$ solution of nitric acid at $100{ }^{\circ} \mathrm{C}$ (Fig. 5d). Structural disturbances were noted only for sample $\mathrm{C}_{\mathrm{ST}}-\mathrm{HNO}_{3}-$ 100-5 (Fig. 5e). The use of $5 \mathrm{M}$ solution of $\mathrm{HNO}_{3}$ at a high temperature probably leads to removal of carbon layers from the carbon particles, so to uneven surface with many cavities.

The functional groups on the surface of mesoporous carbons determine their adsorption, electrochemical, catalytic, acid-base, red-ox, hydrophilichydrophobic and other properties. The $\mathrm{C}_{\mathrm{ST}}$ oxidation with ammonium persulfate or nitric acid solutions leads to generation of numerous functional groups, the same as occur in typical organic compounds. The content of acidic and basic oxygen functional groups was evaluated by the Boehm method [32], and the 

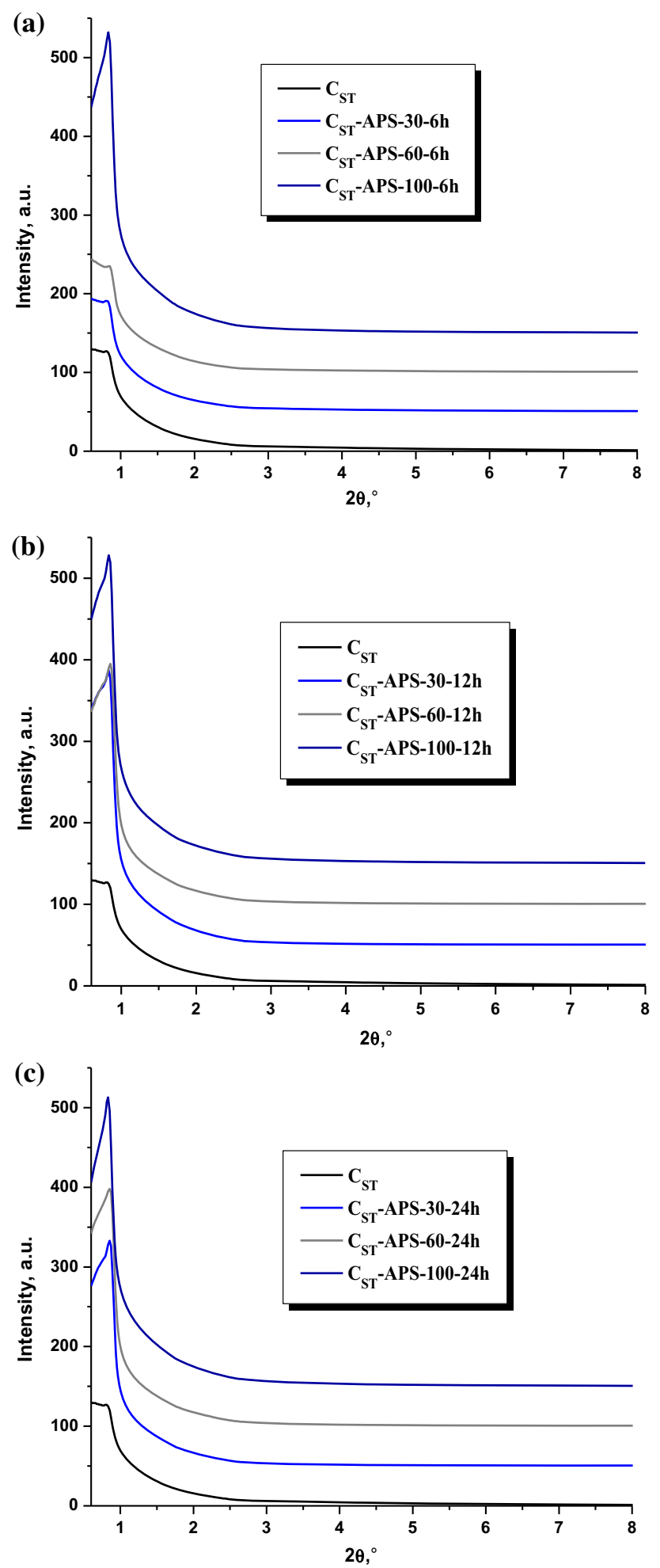

Figure 3 XRD patterns of pristine OMC and samples oxidized in acidic APS solution at 30,60 and $100{ }^{\circ} \mathrm{C}$ for 6 (a), 12 (b) and $24 \mathrm{~h}(\mathrm{c})$.

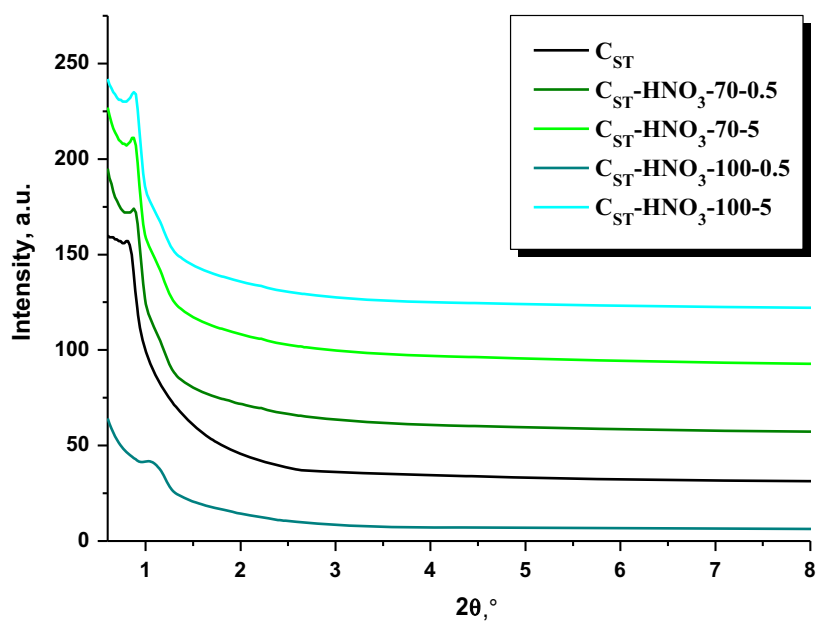

Figure $4 \mathrm{XRD}$ patterns of pristine $\mathrm{OMC}$ and samples oxidized in 0.5 and $5 \mathrm{M} \mathrm{HNO}_{3}$ solutions at 70 and $100{ }^{\circ} \mathrm{C}$.

results are present in Table 2. As follows from this table, the oxidation of mesoporous carbon causes an increase in the number of oxygen functional groups of acidic character, and their content depends first of all on the conditions of the process and the type of oxidizing agent. No surface oxygen functional groups of basic character were found on the samples oxidized with a solution of $\left(\mathrm{NH}_{4}\right)_{2} \mathrm{~S}_{2} \mathrm{O}_{8}$ at 30 or $60{ }^{\circ} \mathrm{C}$, irrespective of the process duration, and on the sample oxidized with $5 \mathrm{M}$ solution of $\mathrm{HNO}_{3}$ at $100{ }^{\circ} \mathrm{C}\left(\mathrm{C}_{\mathrm{ST}}-\mathrm{HNO}_{3}-100-5\right)$. The content of acidic functional groups increased with increasing temperature of the process and varied from 1.87 to $4.55 \mathrm{mmol} / \mathrm{g}$ for the samples oxidized with $\left(\mathrm{NH}_{4}\right)_{2-}$ $\mathrm{S}_{2} \mathrm{O}_{8}$ solution and from 1.92 to $8.13 \mathrm{mmol} / \mathrm{g}$ for the samples oxidized with $\mathrm{HNO}_{3}$ solutions. It should be noted that also the concentration of nitric acid influences the content of oxygen functional groups on the surface of the samples oxidized $\mathrm{HNO}_{3}$, the use of $0.5 \mathrm{M}$ solution of $\mathrm{HNO}_{3}$ led to generation of a smaller number of oxygen functional groups of acidic character than the use of $5 \mathrm{M}$ solution of this acid.

The FT-IR study was performed to check for possible changes in the chemical composition of the carbon materials studied as a result of oxidation. The FT-IR spectra definitely confirm generation of oxygen functional groups upon oxidation, which is manifested by the appearance of a band at $1721 \mathrm{~cm}^{-1}$, assigned in the literature to the vibrations of $\mathrm{C}=\mathrm{O}$ in carboxyl groups, esters, lactones and quinones (Figs. 6, 7). The bands at the wavenumber $1590 \mathrm{~cm}^{-1}$, whose intensity increased after oxidation, originate 
(a)

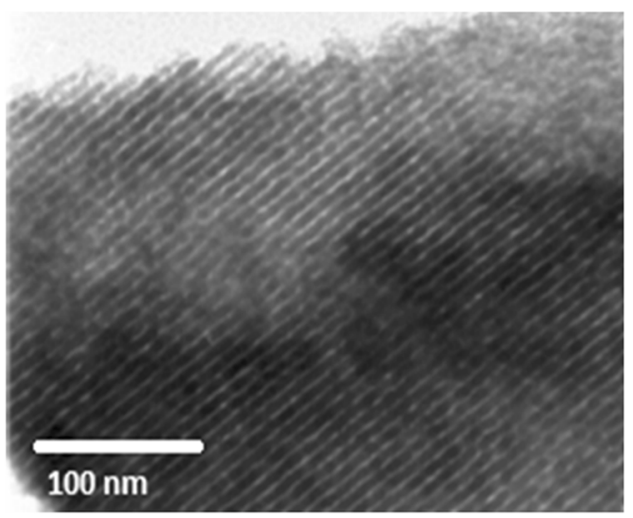

(b)

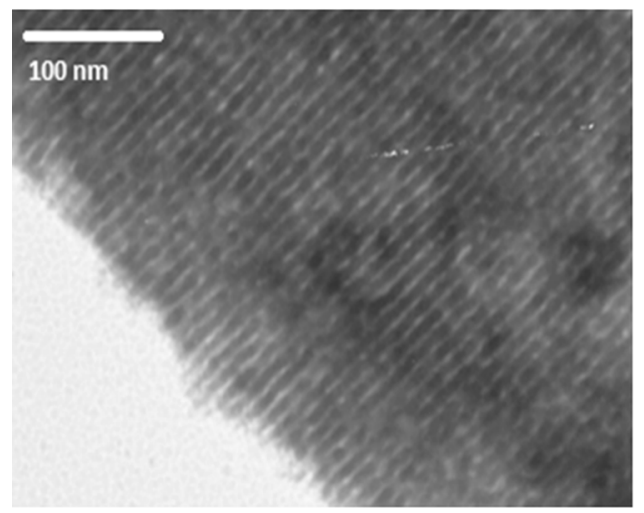

(d)

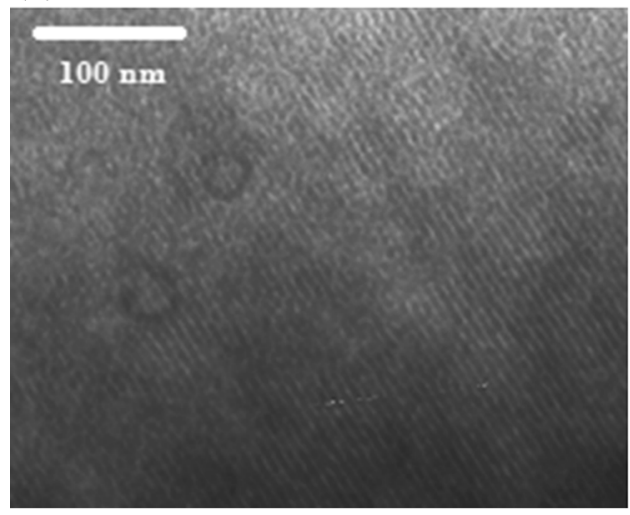

(c)

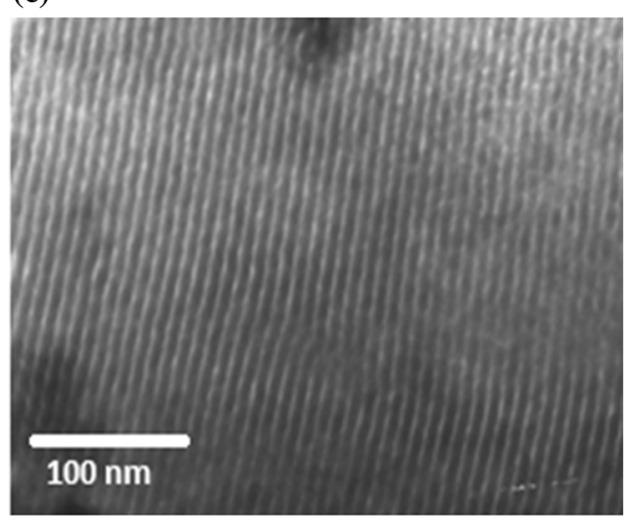

(e)

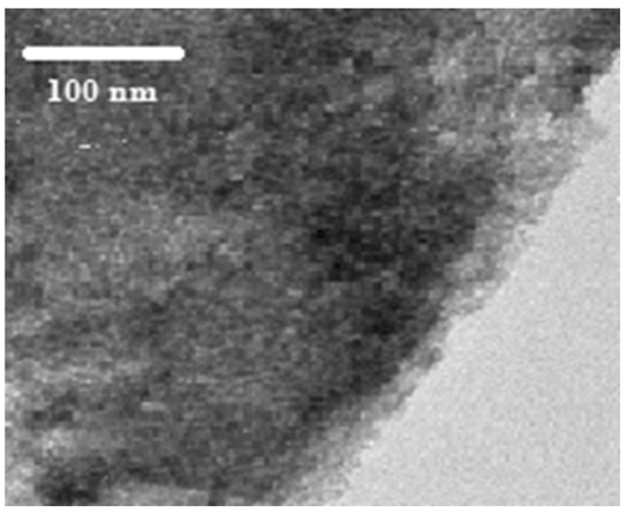

Figure 5 TEM images of pristine mesoporous carbon (a) and samples after the treatment in a $1.0 \mathrm{M}$ acidic APS solution at $30{ }^{\circ} \mathrm{C}$ (b), $100{ }^{\circ} \mathrm{C}$ for $24 \mathrm{~h}(\mathbf{c})$ and after the treatment in $0.5 \mathrm{M}(\mathbf{d}), 5.0 \mathrm{M} \mathrm{HNO}_{3}$ solution at $100{ }^{\circ} \mathrm{C}(\mathbf{e})$.

from $\mathrm{COO}^{-}$groups, while those at 1215 and $1120 \mathrm{~cm}^{-1}$, from the stretching vibrations of $\mathrm{C}-\mathrm{O}$ bond. The bands at $3433 \mathrm{~cm}^{-1}$ are assigned in the literature to $-\mathrm{OH}$ groups $[33,34]$. Irrespective of the type of oxidizing agent, the FT-IR spectra of the oxidized carbon samples show similar absorption bands. It should be mentioned that all the spectra assigned to the oxygen functional groups are the most intensive for the sample modified with $5 \mathrm{M}$ solution of $\mathrm{HNO}_{3}$ at $100{ }^{\circ} \mathrm{C}$ (Fig. 7).

Thermogravimetric analysis (TG) and derivative thermogravimetric analysis (DTG) were used to examine the content and type of the functional groups. Figure $8 \mathrm{a}, \mathrm{b}$ presents the TG curves informing about mass changes of the samples $\mathrm{C}_{\mathrm{ST}}, \mathrm{C}_{\mathrm{ST}}$-APS30-24h, $\mathrm{C}_{\mathrm{ST}^{-}}$-APS-60-24h, $\mathrm{C}_{\mathrm{ST}^{-}}$-APS-100-24h recorded on heating from 20 to $1000{ }^{\circ} \mathrm{C}$ in flowing nitrogen. 
Table 2 Acid-base properties of mesoporous carbons

\begin{tabular}{llll}
\hline Sample & Acidic groups $(\mathrm{mmol} / \mathrm{g})$ & Basic groups $(\mathrm{mmol} / \mathrm{g})$ & Total content of surface oxides $(\mathrm{mmol} / \mathrm{g})$ \\
\hline $\mathrm{C}_{\mathrm{ST}}$ & 1.11 & 0.74 & 1.85 \\
$\mathrm{C}_{\mathrm{ST}}$-APS-30-6h & 1.87 & 0.00 & 1.87 \\
$\mathrm{C}_{\mathrm{ST}}$-APS-30-12h & 3.63 & 0.00 & 3.63 \\
$\mathrm{C}_{\mathrm{ST}}$-APS-30-24h & 4.04 & 0.00 & 4.04 \\
$\mathrm{C}_{\mathrm{ST}}$-APS-60-6h & 2.11 & 0.00 & 2.11 \\
$\mathrm{C}_{\mathrm{ST}}$-APS-60-12h & 4.28 & 0.00 & 4.28 \\
$\mathrm{C}_{\mathrm{ST}}$-APS-60-24h & 4.55 & 0.00 & 4.55 \\
$\mathrm{C}_{\mathrm{ST}}$-APS-100-6h & 3.08 & 0.50 & 3.58 \\
$\mathrm{C}_{\mathrm{ST}}-\mathrm{APS}-100-12 \mathrm{~h}$ & 3.23 & 0.37 & 3.60 \\
$\mathrm{C}_{\mathrm{ST}}-\mathrm{APS}_{-100-24 \mathrm{~h}}$ & 3.38 & 0.12 & 3.50 \\
$\mathrm{C}_{\mathrm{ST}}-\mathrm{HNO}_{3}-70-0.5$ & 1.92 & 0.25 & 2.17 \\
$\mathrm{C}_{\mathrm{ST}}-\mathrm{HNO}_{3}-70-5$ & 2.10 & 0.25 & 2.35 \\
$\mathrm{C}_{\mathrm{ST}}-\mathrm{HNO}_{3}-100-0.5$ & 2.29 & 0.13 & 2.42 \\
$\mathrm{C}_{\mathrm{ST}}-\mathrm{HNO}_{3}-100-5$ & 8.13 & 0.00 & 8.13 \\
\hline
\end{tabular}

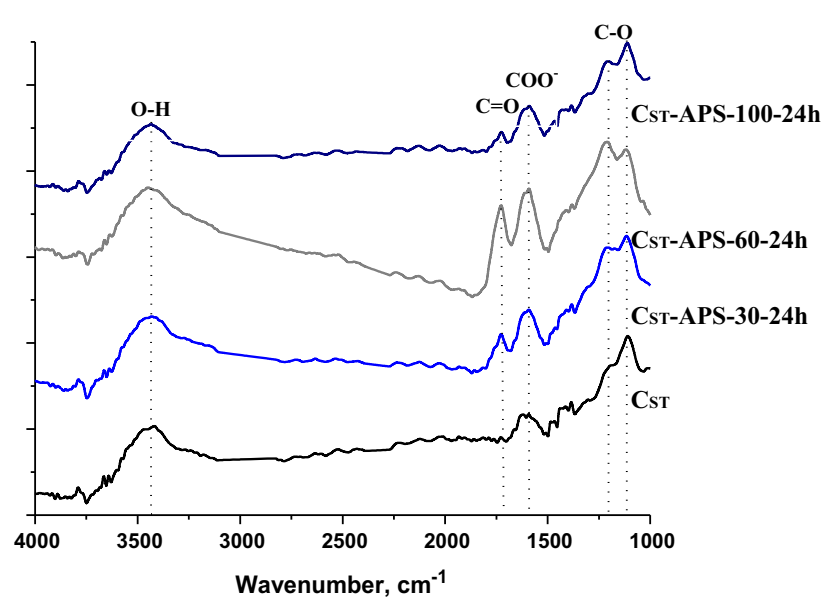

Figure 6 FT-IR spectra of OMC before and after oxidation with 1 M APS solution.

The mass loss of pristine $\mathrm{C}_{\mathrm{ST}}$ sample is small, barely about $4 \%$. Much greater changes are observed for the materials subjected to functionalization. For carbons oxidized with $\left(\mathrm{NH}_{4}\right)_{2} \mathrm{~S}_{2} \mathrm{O}_{8}$ solution at 30 and $100{ }^{\circ} \mathrm{C}$ for $24 \mathrm{~h}$ ( $\mathrm{C}_{\mathrm{ST}_{\mathrm{T}}}$-APS-30-24h, $\mathrm{C}_{\mathrm{ST}}$-APS-100-24h), the mass loss reaches 33 and $24 \%$, respectively. The greatest mass changes, of about $37 \%$, are noted for carbon functionalized with $\left(\mathrm{NH}_{4}\right)_{2} \mathrm{~S}_{2} \mathrm{O}_{8}$ solution at $60{ }^{\circ} \mathrm{C}$. The mass loss observed for $\mathrm{C}_{\mathrm{ST}^{-}}-\mathrm{HNO}_{3}-70-0.5$, $\mathrm{C}_{\mathrm{ST}}-\mathrm{HNO}_{3}-100-0.5$ and $\mathrm{C}_{\mathrm{ST}}-\mathrm{HNO}_{3}-70-5$ oxidized with $\mathrm{HNO}_{3}$ solution (Fig. 9a) reaches 18, 29 and 26\%, respectively, while for the sample with the greatest content of surface oxygen functional groups, $\mathrm{C}_{\mathrm{ST}^{-}}$ $\mathrm{HNO}_{3}-100-5$, the mass loss reaches $51 \%$ (Fig. 9a). The

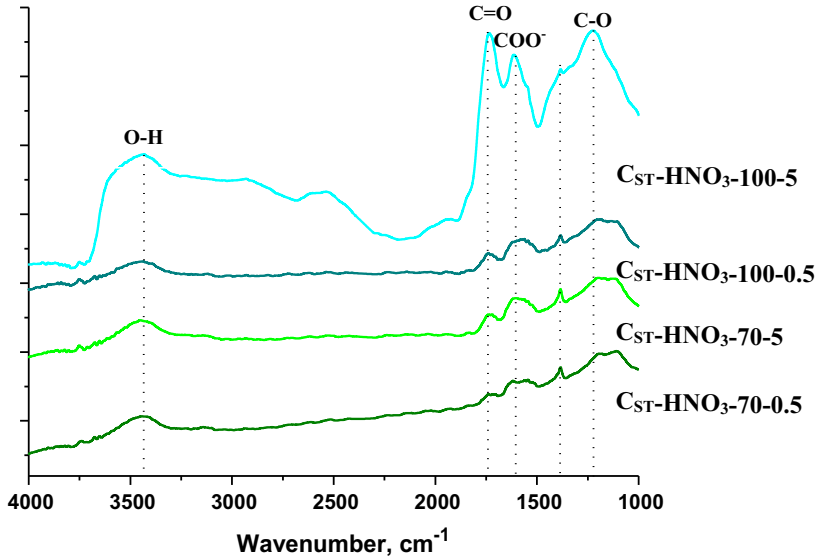

Figure 7 FT-IR spectra of OMC after oxidation with 0.5 and $5 \mathrm{M}$ $\mathrm{HNO}_{3}$ solutions.

functional groups generated on the surface of the carbon samples undergo thermal decomposition in three stages. The first in the range $150-350{ }^{\circ} \mathrm{C}$ can be assigned to decomposition of carboxyl and phenol groups. The mass loss in the range $350-650{ }^{\circ} \mathrm{C}$ is a consequence of decomposition of ester, quinone and anhydride groups. Temperatures above $650{ }^{\circ} \mathrm{C}$ may cause further decomposition of more stable oxygencontaining functional groups and self-decomposition of OMC $[33,34]$. 
(a)
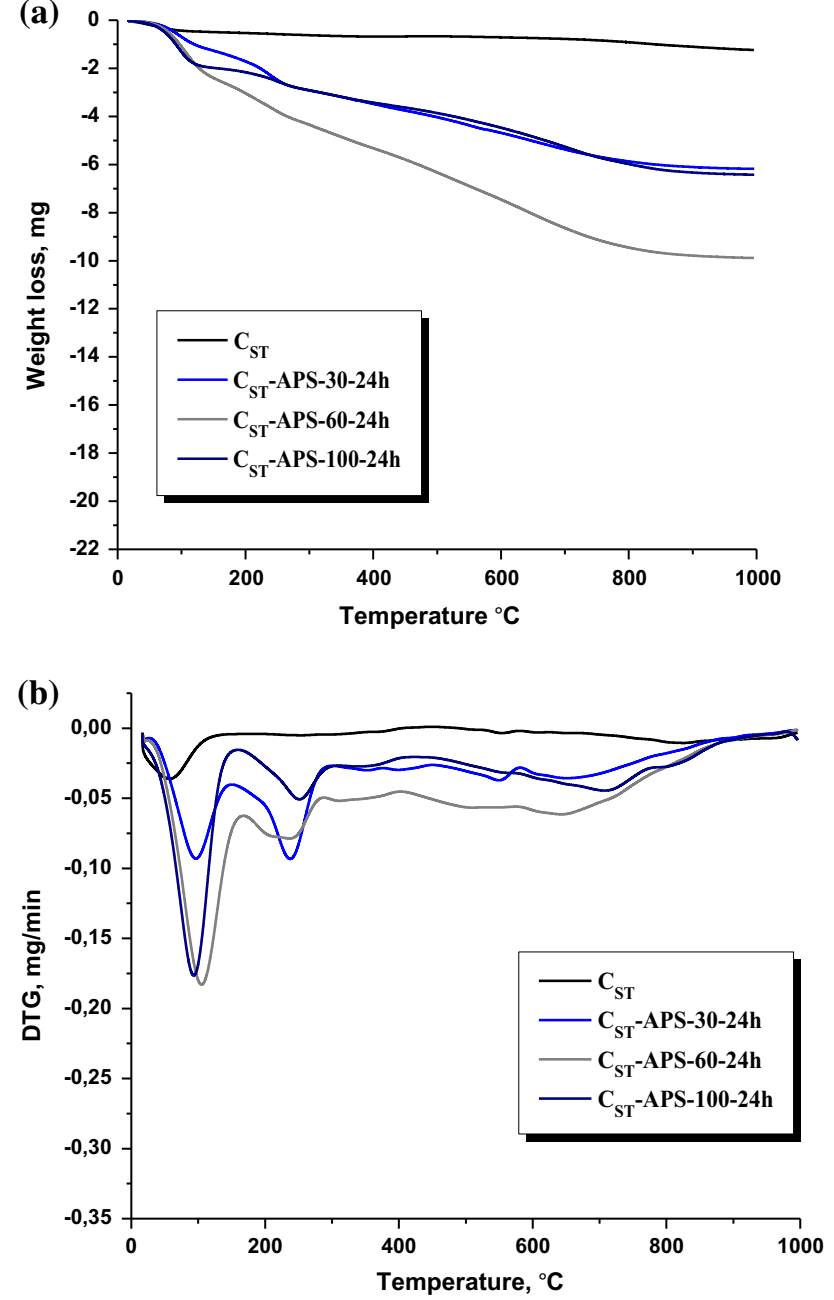

Figure 8 TG (a) and DTG (b) curves of pristine mesoporous carbons $\mathrm{C}_{\mathrm{ST}}$ and oxidized in APS solution at 30,60 and $100{ }^{\circ} \mathrm{C}$ for $24 \mathrm{~h}$.

\section{Conclusions}

The effects of oxidation of ordered mesoporous carbon sample, synthesized by the soft template method, with solutions of ammonium persulfate and nitric acid, were studied. The influence of the type of oxidizing agent and oxidation conditions on the physicochemical properties of the carbon material were examined. The functionalization with solution of $\left(\mathrm{NH}_{4}\right)_{2} \mathrm{~S}_{2} \mathrm{O}_{8}$, irrespective of the process conditions, did not lead damage the ordered carbon structure. The modification resulted in an increase in the surface area and pore volume, except for the samples oxidized at 30 and $60^{\circ} \mathrm{C}$ for $6 \mathrm{~h}$, whose micropores were blocked by the oxygen functional groups. Functionalization of mesoporous carbon $\mathrm{C}_{\mathrm{ST}}$ with a
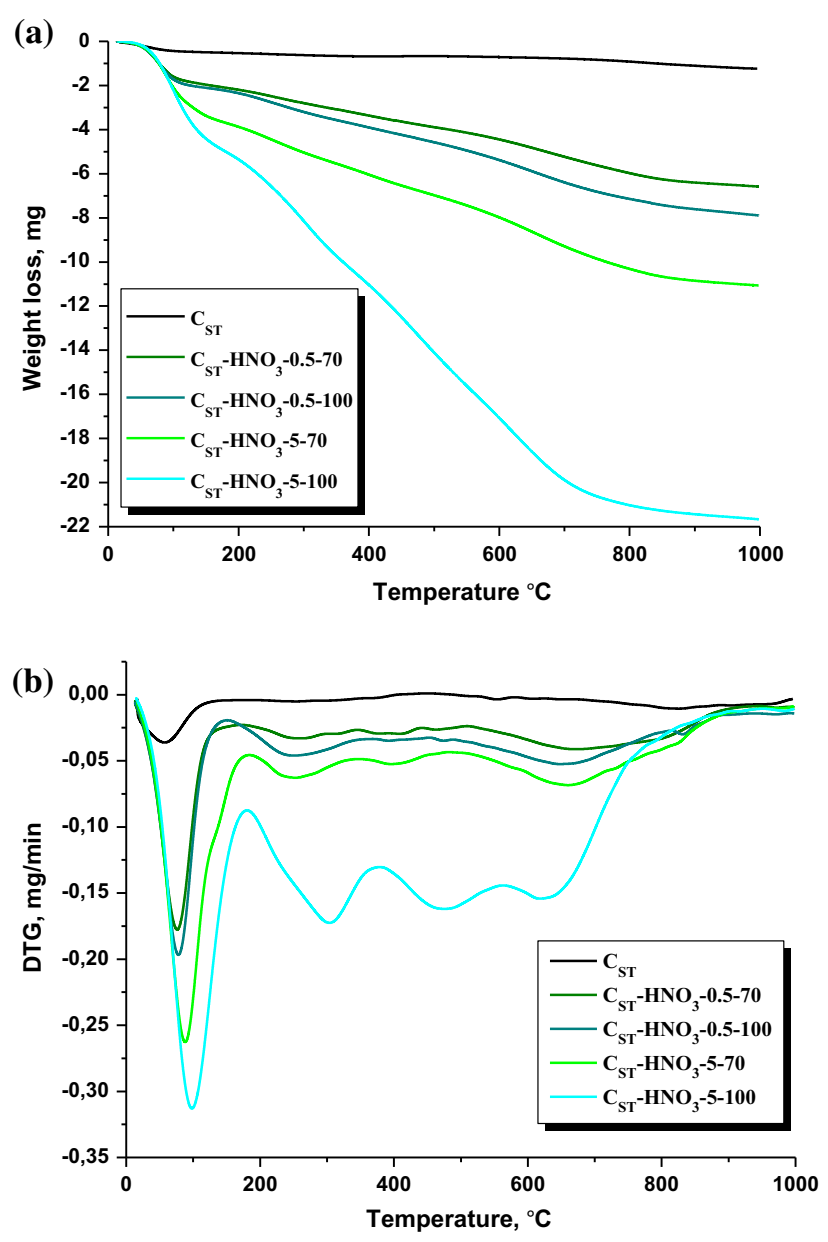

Figure 9 TG (a) and DTG (b) curves of pristine mesoporous carbons $\mathrm{C}_{\mathrm{ST}}$ and oxidized with 0.5 and $5.0 \mathrm{M} \mathrm{HNO}_{3}$ solutions at 70 and $100{ }^{\circ} \mathrm{C}$ for $12 \mathrm{~h}$.

$\mathrm{HNO}_{3}$ solution led to deterioration of its textural parameters, and if the process was performed at a high temperature, to partial destruction of the ordered structure. The number of generated functional groups depended first of all on the type of oxidizing agent and conditions of the process. The FT-IR and Boehm method measurements proved that the use of $\mathrm{HNO}_{3}$ permitted generation of the greatest number of oxygen functional groups at a high temperature, $8.13 \mathrm{mmol} / \mathrm{g}$. The greatest number of oxygen functional groups on the surface of $\mathrm{C}_{\mathrm{ST}}$ functionalized with $\left(\mathrm{NH}_{4}\right)_{2} \mathrm{~S}_{2} \mathrm{O}_{8}(4.55 \mathrm{mmol} / \mathrm{g})$ was generated at $60{ }^{\circ} \mathrm{C}$ for the process duration of $24 \mathrm{~h}$.

\section{Compliance with ethical standards}

Conflict of interest The authors declare that they have no conflict of interest. 


\section{Open Access}

This article is distributed under the terms of the Creative Commons Attribution 4.0 International License (http://creativecommons.org/licenses/by/ $4.0 /$ ), which permits unrestricted use, distribution, and reproduction in any medium, provided you give appropriate credit to the original author(s) and the source, provide a link to the Creative Commons license, and indicate if changes were made.

\section{References}

[1] Ryoo R, Joo SH, Kruk M, Jaroniec M (2001) Ordered Mesoporous Carbons. Adv Mater 13:677-681

[2] Ryoo R, Joo SH, Jun S (1999) Synthesis of highly ordered carbon molecular sieves via template-mediated structural transformation. J Phys Chem B 103:7743-7746

[3] Jun S, Joo SH, Ryoo R, Kruk M, Jaroniec M, Liu Z, Ohsuna T, Terasaki O (2000) Synthesis of new nanoporous carbon with hexagonally ordered mesostructured. J Am Chem Soc 122:10712-10713

[4] Bandura L, Franus M, Panek R, Woszuk A, Franus W (2015) Charakterystyka zeolitów i ich zastosowanie jako adsorbentów substancji ropopochodnych. Przem Chem 94:323-327

[5] Bandura L, Panek R, Rotko M, Franus W (2016) Synthetic zeolites from fly ash for an effective trapping of BTX in gas stream. Micropor Mesopor Mater 223:1-9

[6] Tanaka S, Nishiyama N, Egashira Y, Ueyama K (2005) Synthesis of ordered mesoporous carbons with channel structure from an organic-organic nanocomposite. Chem Commun. https://doi.org/10.1039/B501259G

[7] Jin J, Nishiyama N, Egashira Y, Ueyama K (2009) Pore structure and pore size controls of ordered mesoporous carbons prepared from resorcinol/formaldehyde/triblock polymers. Micropor Mesopor Mater 118:218-223

[8] Górka J, Zawiślak A, Choma J, Jaroniec M (2008) $\mathrm{KOH}$ activation of mesoporous carbons obtained by soft-templating. Carbon 46:1159-1161

[9] Goscianska J, Marciniak M, Pietrzak R (2015) Ordered mesoporous carbons modified with cerium as effective adsorbents for azo dyes removal. Sep Purif Technol 154:236-245

[10] Goscianska J, Olejnik A, Pietrzak R (2013) Adsorption of Lphenylalanine onto mesoporous silica. Mater Chem Phys 142:586-593

[11] Beck JS, VartUli JC, Roth WJ, Leonowicz ME, Kresge CT, Schmitt KD, Chu CTW, Olson DH, Sheppard EW, McCullen
SB, Higgins JB, Schlenkert JL (1992) A new family of mesoporous molecular sieves prepared with liquid crystal templates. J Am Chem Soc 114:10834-10843

[12] Goscianska J, Olejnik A, Pietrzak R (2014) Adsorption of Lphenylalanine on ordered mesoporous carbons prepared by hard template method. J Taiwan Inst Chem Eng 45:347-353

[13] Liang CD, Li ZJ, Dai S (2008) Mesoporous carbon materials: synthesis and modification. Angew Chem Int Ed 47:3696-3717

[14] Goscianska J, Marciniak M, Pietrzak R (2014) Mesoporous carbons modified with lanthanum(III) chloride for methyl Orange adsorption. Chem Eng J 247:258-264

[15] Sterk L, Górka J, Vinu A, Jaroniec M (2012) Soft-templating synthesis of ordered mesoporous carbons in the presence of tetraethyl orthosilicate and silver salt. Micropor Mesopor Mater 156:121-126

[16] Goscianska J, Olejnik A, Pietrzak R (2013) In vitro release of L-phenylalanine from ordered mesoporous materials. Micropor Mesopor Mater 177:32-36

[17] Górka J, Fenning C, Jaroniec M (2009) Influence of temperature, carbon precursor/copolymer ratio and acid concentration on adsorption and structural properties of mesoporous carbons prepared by soft templating. Colloids Surf A 352:113-117

[18] Liang C, Hong KL, Guiochon GA, Mays JW, Dai S (2004) Synthesis of a large-scale highly ordered porous carbon film by self-assembly of block copolymers. Angew Chem Int Ed 43:5785-5789

[19] Zhang F, Meng Y, Gu D, Yan Y, Yu C, Tu B, Zhao D (2005) A facile aqueous route to synthesize highly ordered mesoporous polymers and carbon frameworks with Ia3d bicontinuous cubic structure. J Am Chem Soc 127:13508-13509

[20] Jun S, Choi M, Ryu S, Lee HY, Ryoo R (2003) Ordered mesoporous carbon molecular sieves with functionalized surfaces. Stud Surf Sci Catal 146:37-40

[21] Chingombe P, Saha B, Wakeman RJ (2005) Surface modification and characterisation of a coal-based activated carbon. Carbon 43:3132-3143

[22] Sánchez-Sánchez A, Suárez-García F, Martínez-Alonso A, Tascón JMD (2013) Surface modification of nanocast ordered mesoporous carbons through a wet oxidation method. Carbon 62:193-203

[23] Song Y, Ye G, Chen J, Lv D, Wang J (2015) Wet oxidation of ordered mesoporous carbon FDU-15 by using $\left(\mathrm{NH}_{4}\right)_{2-}$ $\mathrm{S}_{2} \mathrm{O}_{8}$ for fast adsorption of $\mathrm{Sr}(\mathrm{II})$ : an investigation on surface chemistry and adsorption mechanism. Appl Surf Sci 357:1578-1586

[24] Darmstadt H, Roy C, Kaliaguine S, Choi SJ, Ryoo R (2002) Surface chemistry of ordered mesoporous carbons. Carbon 40:2673-2680 
[25] Wang D, Li F, Liu M, Cheng H (2007) Improved capacitance of SBA-15 templated mesoporous carbons after modification with nitric acid oxidation. New Carbon Mater 22:307-314

[26] Prato M, Kostarelos K, Bianco A (2008) Functionalized carbon nanotubes in drug design and discovery. Acc Chem Res 41:60-68

[27] Dongil AB, Bachiller-Baeza B, Guerrero-Ruiz A, Rodr1guez-Ramos I, Martínez-Alonso A, Tascón JMD (2011) Surface chemical modifications induced on high surface area graphite and carbon nanofibers using different oxidation and functionalization treatments. $\mathrm{J}$ Colloid Interface Sci 355:179-189

[28] Seredych M, Hulicova-Jurcakova D, Lu GQ, Bandosz TJ (2008) Surface functional groups of carbons and the effect on their chemical character, density and accessibility to ions on electrochemical performance. Carbon 46:1475-1488

[29] Calvillo L, Lazaro MJ, Garcia- Bordeje E, Moliner R, Cabot PL, Esparbe I, Pastor E, Quinatana JJ (2007) Platinum supported on functionalized ordered mesoporous carbon as electrocatalyst for direct methanol fuel cells. J Power Sources 169:59-64
[30] Bazuła PA, Lu A, Nitz J, Schüth F (2008) Surface and pore structure modification of ordered mesoporous carbons via a chemical oxidation approach. Micropor Mesopor Mater 108:266-275

[31] Moreno-Tovar R, Terrés E, Rene Rangel-Mendez J (2014) Oxidation and EDX elemental mapping characterization of an ordered mesoporous carbon: $\mathrm{Pb}(\mathrm{II})$ and $\mathrm{Cd}(\mathrm{II})$ removal. Appl Surf Sci 303:373-380

[32] Boehm HP (1994) Some aspects of the surface chemistry of carbon blacks and other carbons. Carbon 32:759-769

[33] Wu Z, Webley PA, Zhao D (2010) Comprehensive study of pore evolution, mesostructural stability, and simultaneous surface functionalization of ordered mesoporous carbon (FDU-15) by wet oxidation as a promising adsorbent. Langmuir 26:10277-10286

[34] Figueiredo JL, Pereira MFR, Freitas MMA, Orfao JJM (1999) Modification of the surface chemistry of activated carbons. Carbon 37:1379-1389 